\title{
Abstraction of Potassium During Sedimentation
}

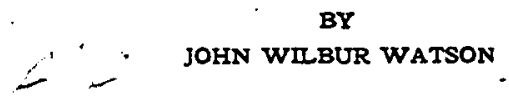

\section{A DISSERTATION}

Presented to the Faculty of the University of Virginia as a Part of the Requirements for the Degree of Doctor of Philosophy

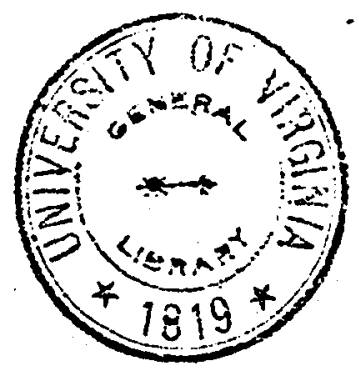





\section{CONTENTS}

Aastractiox of Potassiom Derisg Sedmentation-Outline of Problem-

Previous Work by Other Investigators.....................

Important facts Developed by Previous Workers-Nature of Absorption

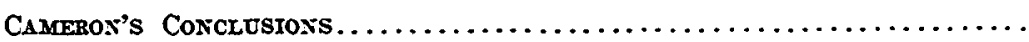

EXPERMMENTAL WORK OF WRITER-Table I. . . . . . . . . . . . . . .

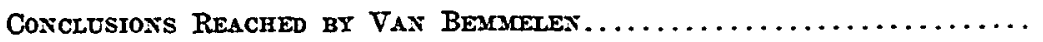

The Writer's Method of Expertmentation.................... 9-10

Discussion of EXPERMMENTS.............................. 10-11

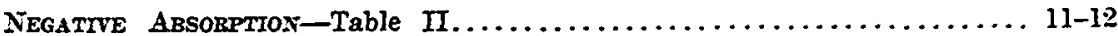

Stminarity of Absorptiox to Soldtion Phexomexa................ 12

Discession of Conclusioxs Reached by Van Bemmetex and Schampt... 13-14

LAW GOVERNING ABSORPTIOX............................ 14

Other Evidesce as to THE NatURE of ABsorption-The Exact Nature of

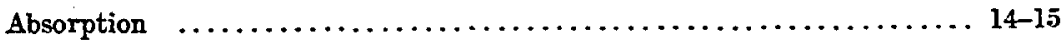

Discussiox of concuesions Reached BY Cayerox axd Others-Adsorption 16-17

Experiarextal Risults of WRITER-Table III.................. 17-18

Process, Catse and Character of adsorption.................. 18-19

FActors INFLdexcixg Adsorption-Table IV-Time of Adsorption-Table

$\nabla$-Absorption of Acid Radical-Table VI-Table VII-Absorption of

Sodium and Lithium-Table VIII...................... 19-24

EXPERIMENTAL WORK INDICATTNG ADSORptiox OF SOdTCM AND LITHTUM-

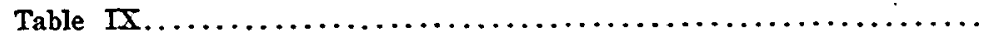

SAIOMON'S WORK ON ABSORPTION OF CALCTOMI-Table X-The Effects of Other

Salts Upon Absorption................................ 25

Experimental WORK of WrTtER-Table XI-Temperature Effect........ 25-27

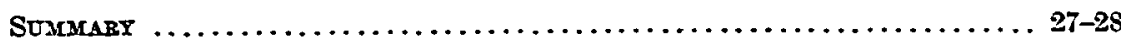

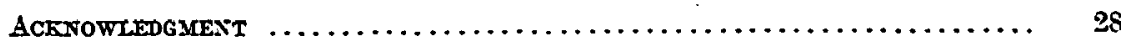

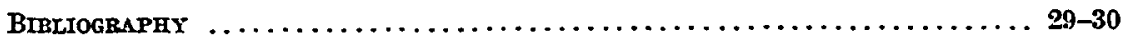




\section{ABSTRACTION OF POTASSIUM DURING SEDIMENTATION}

Outline of Problem.-Primarily this paper seeks to determine whether the absorption of potassium during sedimentation is chemical or physical in nature; secondly, to determine whether the abstraction of potassium differs in hind or degree from that of other bases; and, finally, to determine whether the potassium is absorbed as flocculation takes place, that is when muddy water mingles with sea. water. A study of these questions involves, of course, minor ones which will be taken up as they are reached.

Previous Work by Other Investigators. - That certain salts are removed from solution as they percolate through soils, has been known for many years. Sand filters for purification of sea water and impure drinking water hare been used since Aristotle's time; and the removal of salts from sea water by percolation through sand or earth filters was practiced in Bacon's day (1) ${ }^{\mathrm{a}}$ Steven Hales in 1739 found that the first portion of sea water passed through stone cisterns was pure (1). A list of other investigators who worked along the same line includes, Berzelius, Matteucie, Humphry Dary. in 1813, Gazzeri in 1819, Lambuschini in 1830, Browner in 1836, Huxtaole in 1848, Bernays in 1849, and Thompson and Way in 1850.

Berzelius filtered salt solutions through sand and found that the salt content was more or less removed; Matteucie found that the concentration of the salt in the solution became successively smaller upon being passed through successive filters (1).

Liebig found that aqueous ammonia passed through a clay filter lost its odor, and this result was verified by Thompson and Huxtable. Way in 1850 showed that soils likewise absorbed potassium, sodium, calcium, and magnesium, not only from solutions of their hydrates, but also their salts of both strong and weak acids, the acid remaining in solution unabsorbed and combined with other bases leached from the soil (1); phosphoric acid, however, was absorbed. Way believed this absorption of bases to be total (1), but Voelcker showed that this was not the case with ammonia, while Peters demonstrated the same to be true with potassium (2). Thus first crept in the idea of distribution, or the partition of a soluble substance between solid and liquid, by which a fraction is always left in solution. Many other investigators who worked on various phases of the problem of absorption of soluble material by soils, are mentioned in Bull. 52, Bureau of Soils, U. S. Dept. of Agriculture, 1908, pp. 13-26.

aNumbers in parentheses refer to references listed at end of paper. 


\section{IMPORTANT FACTS DEVEIOPED BY PREVIOUS WORKERS.}

The main fact developed by practically all investigators upon absorption which the writer wishes to emphasize, is that potassium will be absorbed more readily than calcium, magnesium, or sodium (3). Potassium is thus selectively absorbed. It is interesting to mention that ammonia and phosphoric acid, which, together with potassium, constitute the essential mineral constituents of plant food, are also selectively absorbed by soils (1). Ordinary soils will abstract more potassium than sodium from solutions in which the salts of both metals are present, even when the sodium is in excess (4). Potassium is removed from natural waters as they percolate through the soil, or else by the suspended silt carried by streams. The sodium is not so largely withdrawn, and hence its relative proportions tend steadily to increase in solution, while potassium is deposited with the sediments (5).

In igneous rocks (average of all types) the proportion of sodium to potassium is nearly equal, whereas in river water it is in the ratio of four $\mathrm{Na}$ to one $\mathrm{K}$; while in the sea it is approximately thirty to one (6). In sedimentary rociss-the average of $\mathrm{Na}_{2} \mathrm{O}$ is 1.21 per cent, and of $\mathrm{K}_{2} \mathrm{O} 3.03$ per cent $(\gamma)$. From a study of the water in closed basins nearly the same proportion of sodium and potassium holds as in the case of ocean water. These results reveal the fact that potassium is partly removed from solution by the soil, partly by the agencies in rivers, and finally by agencies in the ocean. The greater amount seems to be removed after reaching the ocean. That the agencies which remove potassium in rivers and the ocean are mainly silt, cannot be doubted from what we know of the way soils remove potassium from solution. This fact will be developed later.

According to Clarke (4), the clays and oozes of the deep sea have been partly leached of their alkalies; but some of the potassium from the original volcanic material with less sodium has been retained in the production of zeolites. Nearer land potassium has been used in the formation of glauconite, and-still nearer, when mechanical sediments appear, similar discrimination is evident, namely, sodium dissolves, but potassium is retained.

The bulk of the silt settles to the bottom as soon as it reaches the ocean, that is on mingling with a solution of electrolytes. Turbid suspensions of clay, kaolin, etc., in water are rapidly cleared by the addition of small quantities of metallic salts. The mingling of silt with sea water involves the same sort of phenomenon (9). It has been frequently observed that 
the suspended material causing the cloudiness of the water from Potomac River as it comes from the faucets will settle if an acid or a strong (slightly hydrolyzed) salt is added, while a base, such as ammonia, prevents settling (10). The latter reference gives numerous cases of the flocculation of precipitates by the addition of electrolytes. This phenomenon resembles in a striking way the precipitation of colloids by certain electrolytes.

Nature of Absorption.-A study of the literature on the subject of absorption leads to the conclusion that absorption is primarily physical, which is confirmed by the experimental work of the writer, although chemical reactions may be involved as a result.

\section{CAMERON'S CONCLUSTONS.}

This writer (11) states that the absorption of potassium by soils cannot be explained by a simple metathetical reaction. Other bases are found in the resulting solution, and they are not present in equivalent quantities to the potash; while the solution is generally acid. Similar results can be obtained with other absorbent media which do not contain any bases to replace potassium. The further fact has been established that an absorbing medium has a finited capacity for taking up any particular substance or constituent, and this capacity or saturation limit is generally independent of any simple molecular ratio between the absorbed substance and any component or constituent of the absorbing medium; organic substances such as dyes being absorbed in precisely the same way as mineral solutes (11).

\section{EXPERIMENTAL WORK OF WRITER.}

Using fire-clay, kaolin, Russian black soil, and a powdered nephelinesyenite, respectively, with a potassium salt solution, the writer obtained results which indicated that the replacement of potassium by other bases is not exact. In each case distilled water dissolves a certain amount of the bases. Even if the amount dissolved by distilled water be allowed for, still the replacement was not exact.

The method of procedure of the wiriter in each case was to place thirty grams of absorbing material in contact with fifty cubic centimeters of salt solution (or quantities in the same ratio) for twenty-four hours, then in one 10 c. c. portion the alkalies were determined, and in another portion the remaining bases. In every case, except with kaolin, a parallel experiment was run with distilled water and the absorbent material. In the case of nepheline-syenite potassium and sodium only were determined. The 
results in each case were calculated to a ten cubic centimeter portion. The strength of the potassium salt solution used in each case ras approximately $1 / 10$ normal.

TABLE I.-Part 1.

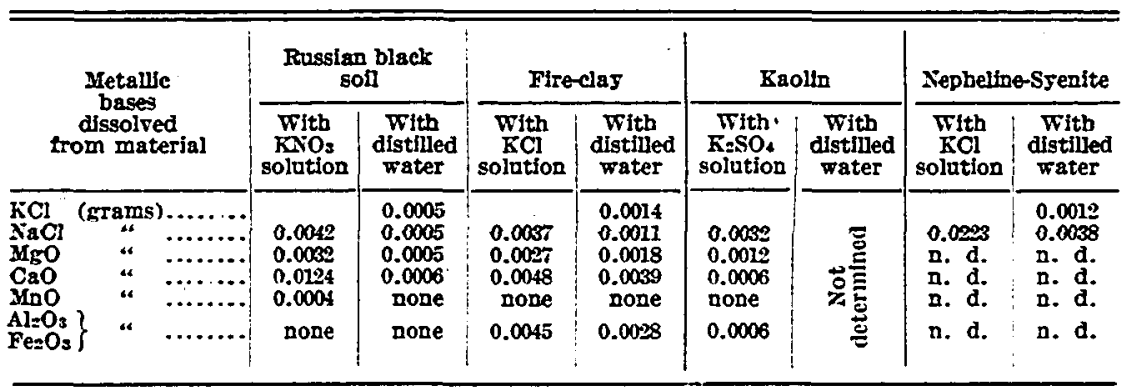

TABLE I.-Part 2.

\begin{tabular}{|c|c|c|c|c|}
\hline $\begin{array}{l}\text { Potassium equivalent } \\
\text { of metals, deducting } \\
\text { amount dissolred by } \\
\text { pure } \mathrm{H}=\mathrm{O} \ldots \ldots \ldots \ldots \ldots\end{array}$ & .0247 & .0079 & .0065 & .0124 \\
\hline $\begin{array}{l}\text { Potassium absorbediby } \\
\text { material (see Table } \\
\text { II. pp. } 11 \text { and 12)... }\end{array}$ & .0208 & .0090 & .0044 & .0131 \\
\hline $\begin{array}{l}\text { Equiv. to potassium| } \\
\text { per cent. metals dis- } \\
\text { solved from absorb- } \\
\text { ent } \ldots \ldots \ldots \ldots \ldots \ldots \ldots\end{array}$ & 108.3 jer cent. & St.7 per cent. & 147.7 per cent. & 94.7 per cent. \\
\hline
\end{tabular}

The $\mathrm{Al}_{2} \mathrm{O}_{3}$ and $\mathrm{Fe}_{3} \mathrm{O}_{3}$ were weighed together and were not determined separately, hence in calculating the $K$ equiralent the mixture was assumed to be one-half $\mathrm{Al}_{2} \mathrm{O}_{3}$ and one-half $\mathrm{Fe}_{2} \mathrm{O}_{3}$. This introduces some error, yet for such small quantities it probably would not make an appreciable difference.

Practically in every case of absorption (see table II) the solution after standing in contact with the soil was tested as to its acidity. Some were acid to litmus, yet in-no case did the writer find the free acid in sufficient quantity to determine by titration. A fraction of a drop of normal base solution proved more than sufficient to make a $5 \mathrm{c}$. c. or $10 \mathrm{c.c}$. portion of the solution alkaline. Fire-clay with $\mathrm{KCl}$ solution was markedly acid; kaolin (high grade) a with $\mathrm{KCl}, \mathrm{KNO}_{3}$, and $\mathrm{K}_{2} \mathrm{SO}_{4}$ solution, respectirely, was slightly acid; kaolin (low grade) ${ }^{a}$ with $\mathrm{KCl}$ solution was

aThese terms refer to the state of purity of the material. The high grade kaolin was extremels pure for a natural substance. whereas the low grade contained a large amount of silica as an impurity. 
slightly acid; the limestone soil with $\mathrm{KCl}, \mathrm{KNO}_{\mathrm{g}}$, and $\mathrm{K}_{2} \mathrm{SO}_{4}$ solution, respectively, was slightly acid; beauxite mith $\mathrm{KCl}$ solution was slightly acid; powdered hematite with $\mathrm{KCl}$ solution very slightly acid. On the other hand, the Russian black soil, powdered rutile granite, sea sand, calcium phosphate, limonite, precipitated calcium carbonate, fluorspar, with the potassium salt (carbonate of potassium excepted of course), proved in each case neutral to litmus. Likerrise the kaolin with $\mathrm{KCl}$ solution and $\mathrm{CaCO}_{3}$ was neutral. The tests with charcoal and potassium salts proved neutral, yet this was doubtless due to the carbonates of the alkalies present in the ash, as the charcoal was not purified (12).

\section{CONCLUSIONS REACHED BY VAN BEMMELEN.}

The work of this investigator (13) in numerous papers on absorption of materials from solution by colloids, indicates that absorption is not primarily a chemical phenomenon. He mentions the fact that it is not a case of substitution when absorption takes places (14). The absorptive power of soils, is attributed by him (15) to colloidal materials mainly, such as colloidal silicates, iron oxide, silicic acid, and humus substances. Even in these cases it would be difficult to see how some of the abore could involve a direct chemical reaction. The fact also developed by him (13), that colloids absorb organic as well as inorganic substances, should preclude the idea of its being a chemical phenomenon in general. According to ran Bemmelen (16) if humus constituents are coagulated from aqueous solution by a small amount of acid or salt, they are very difficult to free of acids or salts by washing; hence he considers this as indicating that the acid or the salt is absorbed by a colloid. This part of his work will be referred to again.

\section{THE WRITER'S METHOD OF EXPERIMENTATION.}

Table II, pp. 11 and 12 , shows the various absorbents used, the different potassium salts employed, the amount of absorption in each case, the amount of sodium coming into solution after absorption, etc. The writer's method of experimentation was as follows: The proportion of absorbent to solution was in the ratio of thirty grams to fifty cubic centimeters of a $N / 10$ solution of potassium salt. The two were shaken up together in a bottle with a glass stopper and left in contact usually about twenty-four hours, though as will be shown later this length of time was really unneces- 
sary. Unless otherwise specified the potassium salt solution was in each case approximately $1 / 10$ normal. $A 5$ or 10 c. c. portion was used for analysis, but the calculation was made always to a $10 \mathrm{c}$. c. basis. The strength of each solution was accurately determined before absorption, hence the amount absorbed was found by difference. The alkalies were determined by the platinum chloride method of J. Lawrence Smith, obtaining sodium by difference; however, in several cases the platinum in the residue was reduced, and the sodium weighed as chloride, simply as a check.

The limestone soil was labeled "limestone-white" from Worthington Valley, Md.; the Russian black soil bore the label, "Tschernosern-Saratoff, State Dep't, Russia"; the kaolin (high grade) came from Graniteville, S. C.; the decomposed granite ("calico" rock) came from near Charlottesville, Va.; the hematite, limonite, fluorspar, calcium phosphate, and beauxite were all in a high state of purity for natural materials.

\section{DISCUSSION OF EXPERIMENTS.}

Taljle II, pp. 11 and 12 , indicates the large number of materials which show absorption, many of which would hardly contain materials to react chemically with the potassium salt. Again, the fact is brought out that absorption cannot be attributed to any one material, such as hydrated silica, but rather the physical nature of the absorbent seems to play an important part, for example, whether in a state of fine subdivision or not. In this connection should be noted the small absorption shown by rock powders, while the decomposed material exhibits in general greater absorption. The order in which potassium is, absorbed from its various salts, apparently depends upon the absorbent. With the limestone soil, the order was, carbonate, nitrate, sulphate, chloride; the kaolin (high grade) showed greatest absorption with the chloride, though the carbonate was fairly close to this, then came the bicarbonate, nitrate, and sulphate, in the order named; the Russian black soil exhibited greatest absorption from the carbonate, then in order the sulphate, nitrate, and chloride. With charcoal the sulphate and chloride showed practically the same amount of absorption. As a rule, the carbonates seem to exhibit the greatest absorption. Treutler (17) in studying the effect of :various fertilizers upon the absorption of potassium by a soil, found that the greatest quantity of potassium was absorbed from the sulphate, carbonate, chloride, and nitrate, in the order named. But the absorption of the potassium from the carbonate and nitrate is more affected by other agencies 
than is the absorption from the sulphate or from the chloride, that from the carbonate being affected to the greatest extent.

\section{NEGATIVE ABSORPTION.}

Lamp black with both potassium chloride and nitrate $e^{\mathrm{a}}$ showed negative absorption, that is the water rather than the solute was absorbed. The chloride solution after standing twenty-four hours in contact with lamp black showed a concentration of .0748 gram $\mathrm{KCl}$ per 10 c. c., as against .0732 gram $\mathrm{KCl}$ per $10 \mathrm{c}$. c. originally, an increase in concentration of .0016 gram $\mathrm{KCl}$ per $10 \mathrm{c}$. c. The nitrate solution after standing twenty-eight hours in contact, showed .1020 gram $\mathrm{KNO}_{3}$ per $10 \mathrm{c}$. c., as against .1008 gram $\mathrm{KNO}_{3}$ originally, an increase in concentration of .0012 gram $\mathrm{KNO}_{3}$ per 10 c. e., of solution. It has been found (18) that charcoal exhibits negative absorption towards certain salts. Van Bemmelen (19) found that kaolin exhibited negative absorption towards sodium chloride. The phenomenon will be referred to again (see p. 17).

TABLE II.

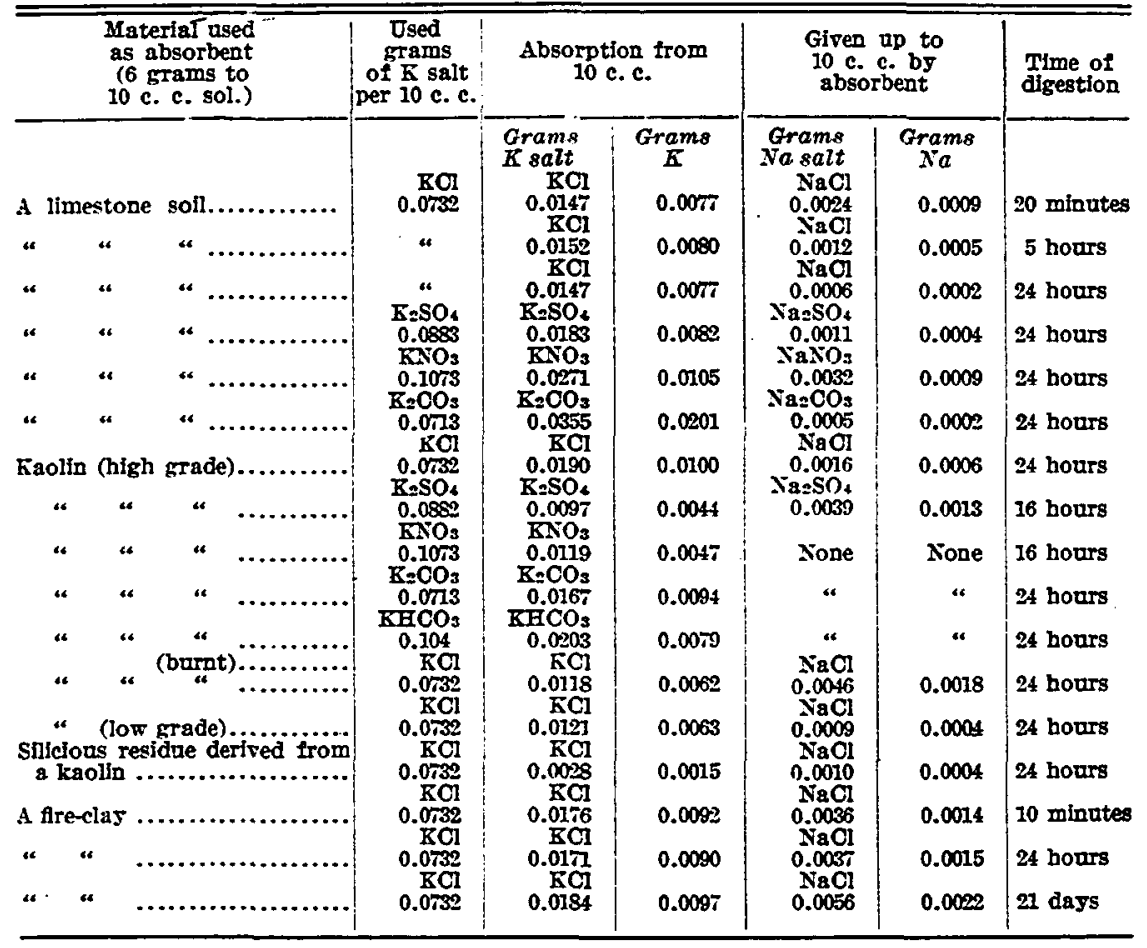

aProportions used in this case were 1.5 grams to 10 c. c. solution. 
TABLE II (Continued).

\begin{tabular}{|c|c|c|c|c|c|c|}
\hline $\begin{array}{c}\text { Ilaterial used } \\
\text { as absorbent } \\
\text { (6 grams to } \\
10 \text { c. c. sol.) }\end{array}$ & $\mid$\begin{tabular}{c|} 
Osed \\
grams \\
of $\mathrm{K}$ salt \\
per $10 \mathrm{c.c}$ c.
\end{tabular} & Absor & on trom & $\begin{array}{l}\text { Given } \\
10 \mathrm{c} . \\
\text { abso }\end{array}$ & $\begin{array}{l}\text { to } \\
\text { by } \\
\text { bent }\end{array}$ & $\begin{array}{l}\text { Time of } \\
\text { digestion }\end{array}$ \\
\hline A fire-clay (finely powdered). & $\begin{array}{r}\mathrm{KCl} \\
0.0732 \\
\mathrm{KCl}\end{array}$ & $\begin{array}{l}\text { Grams } \\
\mathrm{K} \text { salt } \\
\mathrm{KCl} \\
0.0186 \\
\mathrm{KCl}\end{array}$ & $\begin{array}{l}\text { Grams } \\
\qquad K \\
0.0098\end{array}$ & $\begin{array}{c}\text { Grams } \\
\text { Na salt } \\
\text { NaCl } \\
0.0082 \\
\text { NaCl }\end{array}$ & $\begin{array}{c}\text { Grams } \\
N a \\
0.0032\end{array}$ & 24 hours \\
\hline A flre-clay (barnt).. & 0.0 .32 & 0.0331 & 0.0016 & 0.0105 & 0.0041 & 24 hours \\
\hline Russlan black soll.. & 0.0732 & $\begin{array}{l}0.0433 \\
\mathrm{KCl}\end{array}$ & 0.0297 & $\frac{0025}{\mathrm{NaCl}}$ & 0.0010 & 24 hours \\
\hline 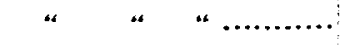 & 0.0732 & 0.0495 & 0.0260 & $\begin{array}{r}0.0015 \\
\times a=S O\end{array}$ & 0.0006 & 15 days \\
\hline 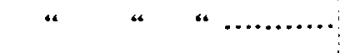 & $\begin{array}{l}0.0883 \\
\mathrm{KNO}\end{array}$ & $\begin{array}{l}0.0595 \\
\mathrm{~K} \mathrm{NO}_{3}\end{array}$ & 0.0267 & $\begin{array}{r}0.0146 \\
\mathrm{Na}_{3}\end{array}$ & 0.0047 & 24 hours \\
\hline$\cdots \quad \cdots, \cdots$ & $\begin{array}{r}0.1008 \\
\mathrm{~K}=\mathrm{CO}\end{array}$ & $\begin{array}{r}0.0590 \\
\mathrm{~K}=\mathrm{CO}_{3}\end{array}$ & $0.0 \times 288$ & $\begin{aligned} 0.0061 \\
\text { YaNos }\end{aligned}$ & 0.0024 & 28 hours \\
\hline$" \quad "$ " $" * .$. & $\begin{array}{rl}0 & 0.03 \\
0.073 \\
\mathrm{KCl}\end{array}$ & $\begin{array}{r}1.203 \\
0.0524 \\
\mathrm{KCl}\end{array}$ & 0.0287 & $\begin{array}{r}\mathrm{Na.ju3} \\
0.0016 \\
\mathrm{iaCl}\end{array}$ & $0.000 r$ & 24 bours \\
\hline " $"$ " & 0.0732 & 0.0956 & 0.0134 & 0.0064 & 0.0025 & 24 hours \\
\hline $\begin{array}{l}\text { Decomposed granite } \\
\text { ("calico" rock) ...... }\end{array}$ & $\begin{array}{r}\mathrm{KCl} \\
0.0732 \\
\mathbf{K C l}\end{array}$ & $\begin{array}{r}\mathrm{KCl} \\
0.00034 \\
\mathrm{KCl}\end{array}$ & 0.0018 & Yone & Sone & 24 hours \\
\hline A granite (tresh powdered).. & $\begin{aligned} 0.0732 \\
\mathrm{KCl}\end{aligned}$ & $\begin{aligned} 0.0015 \\
\mathrm{KCl}\end{aligned}$ & 0.0008 & 0.0025 & 0.0010 & 24 hours \\
\hline from Sorway) ................. & 0.0732 & 0.0015 & 0.0008 & 0.0018 & 0.0007 & 24 hours \\
\hline $\begin{array}{l}\text { syenite) } \\
\text { sea sand "washed, pow- }\end{array}$ & $\begin{array}{r}0.0732 \\
\mathbf{K} \mathbf{C l}\end{array}$ & $\begin{array}{r}0.0250 \\
\mathbf{K C l}\end{array}$ & 0.0131 & 0.0223 & 0.0098 & 24 hours \\
\hline 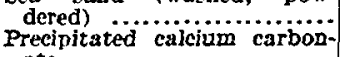 & 0.0732 & 0.0028 & 0.0015 & 0.0038 & 0.0015 & 24 hours \\
\hline ate $\ldots \ldots \ldots \ldots \ldots \ldots \ldots \ldots \ldots \ldots$ & $\begin{array}{r}0.0732 \\
\mathrm{KCl}\end{array}$ & $\begin{array}{r}0.0042 \\
\mathrm{KCI}\end{array}$ & 0.0022 & 0.0126 & 0.0050 & 6 days \\
\hline Sative calcium phosphate... & 0.0732 & 0.0034 & 0.0018 & None & None & 40 bours \\
\hline Hematite (poirdered crystals) & 0.0732 & 0.0012 & 0.0006 & 0.0025 & 0.0010 & 24 hours \\
\hline Limonite (powdered) & 0.0732 & 0.0012 & 0.0006 & 0.0010 & 0.0004 & 24 hours \\
\hline Beauxite (powdered).... & 0.0728 & 0.0075 & 0,0039 & 0.0054 & 0.0021 & 24 bours \\
\hline Fluorspar (nowdered).. & 0.0732 & None & None & Yone & Sone & 24 bours \\
\hline Charcoaln & 0.0732 & 0.0054 & 0.0028 & 0.0008 & 0.0039 & 16 hours \\
\hline Charcoalb & $\begin{array}{l}\mathrm{K} \\
0.08 \mathrm{SO}_{4} \\
0.0883\end{array}$ & $\begin{array}{l}\mathrm{K}=\mathrm{SO} 4 \\
0.0053\end{array}$ & 0.0024 & $\begin{aligned} & \operatorname{Na}=S \\
0.0 & \end{aligned}$ & 0.0012 & 16 hours \\
\hline Chareoale ..... & 0.0366 & 0.0044 & 0.0023 & 0.0021 & 0.0011 & 16 hours \\
\hline
\end{tabular}

AProportions used in this case, $10 \mathrm{grams}$ charcoal to 50 e. c. solution.

Proportions used in this case, 3 grams charcoal to $20 \mathrm{c}$. c. solution.
eProportions used in this case, 10 grams charcoal to $50 \mathrm{c}$. c. solution.

\section{SIMUIARITY OF ABSORPTION TO SOLUTION PHENOMENA.}

Another fact which confirms absorption as being a physical phenomenon, is that it resembles in so many ways well-known solution phenomena, and there is a distribution of the substance, which is being absorbed, between the solid absorbing and liquid media, the resulting concentration of the latter depending upon the amount of the absorbed material in the solid $(20)$. 


\section{DISCUSSION OF CONCLUSIONS REACHED BY VAN BEMMELEN AND SCHMIDT.}

In his (21) work upon the absorption of various solid materials in solution by colloids, among them potassium sulphate by the red colloid of $\mathrm{MnO}_{2}$, van Bemmelen found in some cases the following formula to hold,

$$
\frac{(\text { concentration in colloid) }}{\text { concentration in solution }}=\text { a constant. }
$$

In general the relation, $\frac{\text { (conc. in colloid) }}{\text { conc. in solution }}=a$ constant,

varied according to the substances used. In $\cdot$ a later paper (22) he finds that the concentration in the hydrogel (colloid) increases nearly proportional to the square root of the concentration in the solution, or

$$
\frac{(\text { conc. in colloid })^{2}}{\text { conc. in solution }}=K \text {. }
$$

He states further that the partition coefficient is not a constant, but a complex function of the concentration, and is dependent on the state of the colloid and the temperature. It appears from his work, however, that for a given absorbent and material to be absorbed, both $n$ and $K$ have definite values which are constant in that particular case. His investigations include the absorption of acids, alkalies, and alkali salts by hydrogels (colloids) of silicic acid, stannic acid, and black and red oxides of manganese. Only as a special case and under special conditions, did he find $\frac{\mathrm{C}_{2}}{\mathrm{C}_{1}}=K$, which would be true if it were a case of solid solution and obeyed Henry's law.

Schmidt (23) using van Bemmelen's results upon silicic acid with $\mathrm{K}_{2} \mathrm{SO}_{4}, \mathrm{KNO}_{3}, \mathrm{KCl}, \mathrm{H}_{2} \mathrm{SO}_{4}, \mathrm{HNO}_{3}$, and $\mathrm{HCl}$, endearored to prove that $\frac{\mathrm{C}_{2}}{\mathrm{C}_{1}}=K$, held in general, or that absorption was a case of solid solution and obeyed Henry's law. But van Bemmelen (21) refuted these conclusions as not holding in general, but simply a special case which was true for certain concentrations, and where the power of absorption was feeble. Schmidt obtained other results which are of value in this connection. He found that iodine absorbed from solution by charcoal obered the rule, $\frac{\left(\mathrm{C}_{2}\right)^{4}}{\mathrm{C}_{1}}=K$. Acetic acid absorbed by animal charcoal fol- 
lows the rule, $\frac{\left(\mathrm{C}_{2}\right)^{2}}{\mathrm{C}_{1}(1-m)}=K$, where $m=$ degree of dissociation. Oxalic acid absorbed by animal charcoal obeyed the rule, $\frac{\left(\mathrm{C}_{2}\right)^{10}}{\mathrm{C}_{1}(1-m)}=K$.

Therefore, instead of $\frac{\mathrm{C}_{2}}{\mathrm{C}_{1}}=K$, a case of solid solution, we have this relation holding for absorption in general, $\frac{\left(\mathrm{C}_{s}\right)^{\mathrm{n}}}{\mathrm{C}_{\mathrm{i}}}=K$, where $n$ and $K$ differ according to the absorbent, the material absorbed, the temperature. etc. This idea will be developed later, when the writer introduces his experimental results (see pp. 17 and 18).

\section{IAW GOVERNING ABSORPTION.}

Another point to be considered is that absorption and leaching of potassium from soils obey similar simple laws, and that the equation is identical in form with the equation describing rate of solution (24). This law is expressed by Cameron (25) as follows, $\frac{d y}{d x}=K(A-\mathrm{y})$, where $y=$ the amoint absorbed, $x=$ amount of solution that has passed, and $A=$ total amount which can ultimately be absorbed by that particular soil from that particular solution, while $K$ is a characteristic constant. If the percolation be kept constant, and $t$ (time) be substituted for $x$, we have simply an equation for a unimolecular reaction, whether physical or chemical. This latter equation seems almost identical with the result found by Lagergreen (26) in adsorption, namely, the rapidity with which adsorption takes place in a given unit of time is proportional to the difference between the mass finally adsorbed, and that adsorbed in time $t$. The significance of this will be evident in the next few pages.

\section{OTHER EVDDENCE AS TO THE NATURE OF ABSORPTION.}

There remains one other point which, it seems to the writer, affords evidence of absorption being a physical phenomenon. The quantity of soluble material absorbed by a soil has a marked influence upon the arrangement of the soil grains into aggregates. Different salts have widely different effects upon the soil structure, and the particular strength of soil solution for which the formation of soil aggregates is a maximum is not the same for each salt (27). Now if absorption were mere chemical replacement of base for base, the physical properties of soil particles ought 
not to be appreciably altered. We know that it is a general chemical principle that one base or element can replace another in a given compound, and the physical properties not be altered to any extent. For example, in minerals, one base occurs replacing another, and yet the crystalline structure is identical with the mineral where such replacement has not occurred.

The Exact Nature of Absorption.-One theory, which at first seemed to present possibilities, must be disposed of, namely, the coagulation of colloids by electrolytes.

According to the latest authorities (28) irreversible colloids such as silicic acid, stannic acid, sulphides $\left(A_{2} \mathrm{~S}_{3},{A s_{2}}_{2} \mathrm{~S}_{5}, \mathrm{CdS}\right)$, iodide, and chloride of silver ( $\mathrm{AgI}, \mathrm{AgCl}$ ), and metals ( $\mathrm{Au}, \mathrm{Pt}, \mathrm{Ag}$ ), as well as finely divided suspensions of clay, kaolin, quartz, carbon, etc., carry a negative charge in a solution of pure water; whereas metallic hydroxides (ferric, aluminium, chromic), and basic substances in general carry positive charges. Such substances in the colloidal condition carrying an electrical charge are readily precipitated by the addition of electrolytes (see ref. (10) on p. 7). Negatively charged colloids are precipitated by the action of positive ions, pnsitively charged colloids by negative ions (Hardy's rule) (29). The precipitating ion is carried down with the colloid.

The idea occurred to the writer that this might have to do primarily with the remoral of potassium from solution, but a study of the facts seems not to accord with this assumption. In the first place, it requires very little of a given electrolyte to produce precipitation, or rather very little is thus remored from solution (30). Again this process seems not to be selective; a sodium salt will act in the same way and as readily as a potassium salt. The precipitating power of 'an electrolyte is a function of the valency of the ion, increasing strongly with the valency. (For univalent, bivalent, and trivalent metals the floceulating power is in the proportion of $1: 30: 1650$ ) (31). This is significant when we remember the large amounts of magnesium and calcium salts in the sea. The degree of hydrolysis has no influence upon the flocculation (32). Further information upon this subject can be obtained by consulting Schulze (33), who has made a quantitative study of the whole subject.

That the coagulation of colloids by electrolytes accounts for the rapid settling or flocculation of silt and fine suspensions when river water reaches the ocean, is granted, but it could hardly account for the great selective removal of potassium over all other bases. When once the potassium is absorbed, then flocculation fixes the whole upon the bottom, but its importance is purely secondary. 

AND OTHERS.

Adsorption.-Cameron (34) mentions that the absorption of a dissolved substance from solution by a soil may be accomplished in three ways. (1) It may be a mechanical inclusion or trapping; distinguished by the term imbibition, the most familiar and striking case being the absorption of water itself by a soil or sponge. (2) It may be a partial taking up of the dissolved substance to form a new compound or solid solution, as probably is the absorption of phosphoric acid by. lime or ferric oxide. Obviously these two would hardly apply to a neutral potassium salt. (3) It may be the result of condensation or concentration of the dissolred substance on or about the surface of the absorbing medium, a phenomenon known as adsorption. This may be defined as the existence of a difference in concentration or density of a film adjacent to a bounding solid and the concentration or density of the mass of the liquid which bathes this solid. As an example, Cameron quotes from Patten, quartz grains adsorbing gentian violet. This dye can be washed off the grains by water.

The phenomcuon adsorption seems to fit in well with the absorption of potassium in general, as will now be shown. Freundlich (36) found the empirical relation:

$\mathrm{y} / \mathrm{m}=\mathrm{Bc} \frac{1}{\mathrm{p}}$, where $y$ is the mass of adsorbed substance, $m$ that of the adsorbent, $c$ the concentration of the unadsorbed portion in solution, and $B$ and $p$ are constants. Or more simply we put it in the form $\mathrm{y} / \mathrm{x}_{\mathrm{n}}^{\frac{1}{\mathrm{n}}}=\mathrm{a}$ constant, or $(\mathrm{y})^{\mathrm{n}} / \mathrm{x}=\mathrm{a}$ constant, where $y=$ mass adsorbed, $x$ that remaining in solution. This, as we see, is the same formula as that mentioned on p. 14. W. Biltz (37) found that the adsorption of arsenious acid by freshly precipitated iron hydroxide could be expressed by the relation, $y / x \frac{1}{3}=0.631$. This important characteristic of all adsorption phenomena is here brought out, viz.: the percentage adsorbed of the total amount of the substance is greater the more dilute the original solution. But with stronger concentrations, of course, a relatively greater amount is adsorbed by weight (less by per cent) than with weaker concentrations. Nernst (38) classifies the work of van Bemmelen and Schmidt, which has already been discussed on pp. 13 and 14 , as belonging to adsorption, and this is readily apparent after what has been devèoped in the writer's discussion. Another example which might be given is that of Bouchonnet (39), who found that ochre adsorbed certain dyes according to the above. Nernst $(40)$ states that the adsorbent is not simply a solvent 
for the adsorbed material. For if that were the case, arsenious acid would have a molecular weight in iron hydroxide one-fifth of that which it has in water (partition law). In water its molecular weight is practically normal; so the assumption of such a large dissociation in iron hydroxide is untenable. From these facts, it is erident that $n$ and $K$ in the expression $\mathrm{C}_{2} / \mathrm{C}_{1} \frac{1}{a}=\mathrm{K}$, will vary according to the adsorbent used, and also the material to be adsorbed. Not always does $n$ come out a whole number. In the case of picric acid between water and silk, Walker and Appleyard (41) found $n=2.7$.

In some cases adsorption may be negative (42), viz.: the solute is less concentrated around the adsorbent than in the remainder of solution. Lamp black with $\mathrm{KCl}$ and $\mathrm{KNO}_{3}$ the writer found to be examples apparently of the above (see p. 11 of this paper). Nernst (42) quotes from Lagergreen the case of sodium chloride with charcoal. Freundlich (43) mentions that negative adsorption is comparatively rare.

\section{EXPERTMENTAL RESULTS OF WRITER.}

These results, which class the absorption of a potassium salt under the head of adsorption, were made using different concentrations of potassium chloride, with Russian black soil, limestone soil, kaolin (low grade), and fireclay, respectively. The results seem fully in accord with those of adsorption phenomena. The method of procedure is the same as that previously described on pp. 9 and 10. The time that the two were in contact was, in all cases, twenty-four hours. The general formula, $C_{2} /\left(C_{1}\right) \frac{1}{n}=\mathrm{K}$, holds, where $C_{1}=$ amount left in solution, $C_{2}=$ amount adsorbed, $n$ and $K$ are constants differing for each adsorbent. . In each case a suitable value for $n$ was selected, and $K$ calculated accordingly. The results are tabulaterl on the page following (Table III). 
TABLE IIII.

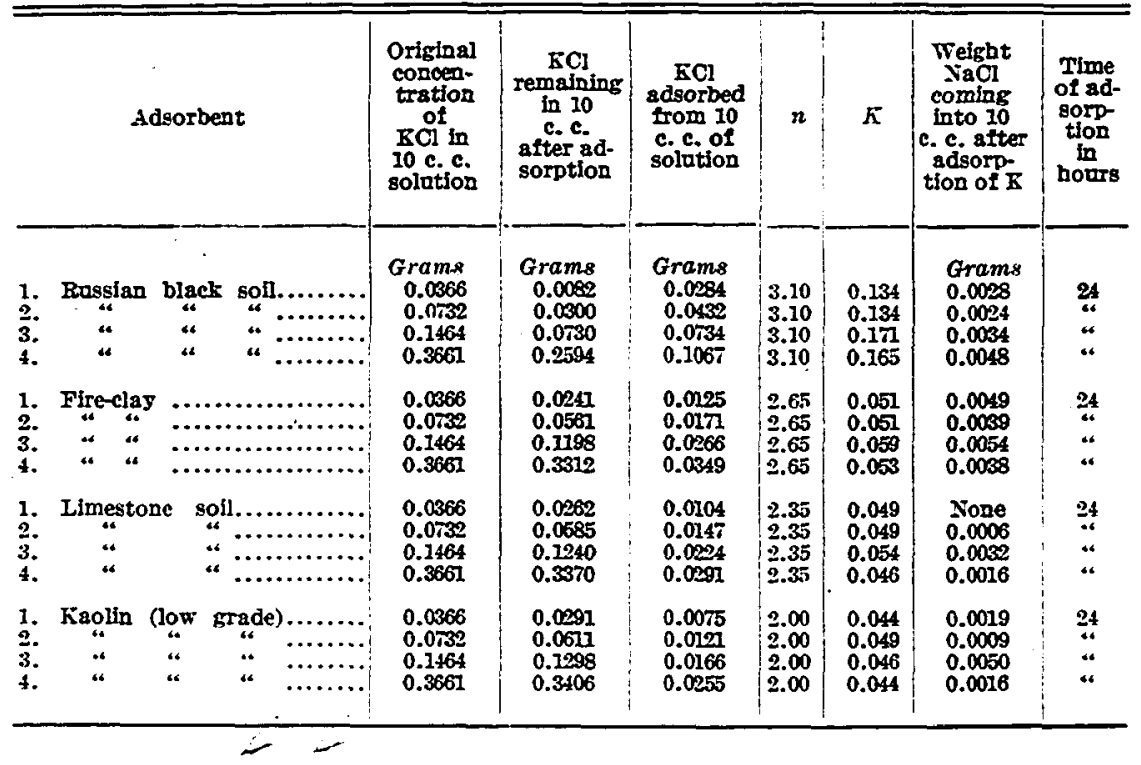

PROCESS, CAUSE, AND CHARACTER OF ADSORPTION.

As will be seen from experimental results and references $(4)$ the acid radical (carbonate excepted) is not adsorbed to any appreciable extent (44). The fact has already been brought out that the solution is often left acid after absorption (45). Patten and Waggaman (45) have shorn that a solution of potassium chloride agitated in contact with a soil, cotton, carbon black, or similar materials which do not themselves react with either the base or the acid, leaves the solution markedly acid. Keith (46) has shown that potassium salts are decomposed by soils yielding some free acid. The work of van Bemmelen (47) is along a similar line. These facts seem to indicate that adsorption promotes hydrolysis of the salts of potassium, by which the acid is left in solution and combines with any other basic material present, while the potassium hydroxide is adsorbed. Way (48) in his experiment upon the absorption of salts by sand, found an excess of the basic substance at the surface of the sand particles. 'Then, of course, if there are sufficient bases in solution to combine with: all the free acid, the solution will be neutral. An analogous case is that found by Loser and Freundlich (49), where certain basic dyes are split in aqueous solution by charcoal, the base being absorbed, and the acid left in solution. The authors class this as a case of adsorption. 
That the acid and not free chloride (in the case of the chloride) is set free, seems evident from the work of Billitzer (50). He could get no coloration of starch iodide paper when tested under the proper conditions.

It is probable that the hydrolysis which precedes adsorption is the result of chemical reaction induced by surfaces. Numerous cases are on record of such action (51). Or it may be a case of progressive hydrolysis promoted by unequal absorption of base (e. g. $\mathrm{KOH}$ ) and acid resulting from hydrolysis.

The literature throws light upon the ultimate cause of selective adsorption in general, and this would hold too for potassium, since it is an adsorption phenomenon. Energy changes are involved in adsorption (52). Ramsden (53) 'says that if a dissolved substance increases the potential energy of a surface it.will seek to leave this surface, while if it diminishes the same it will seek to concentrate upon the surface. Freundlich (54) brings out this same idea, and attributes adsorption phenomena to changes of surface tension, and gives the law (quoted from Gibbs), that substances which lowrer the surface tension must be adsorbed, and vice versa. In case the surface tension between solid and liquid is lowered by the addition of a substance soluble in the liquid, it follows that there will be adsorption of the substance on the surface of the solid, for the potential energy will tend to become lower by further concentration at the bounding surface. This theory seems to be well substantiated.

Adsorption is always selective in character. This is noted in the case of dyes (55), and the absorption of dyes is regarded as adsorption phenomenon (56). Cameron (57) has pointed out that organic substances such as dyes are absorbed in precisely the same manner as mineral solutes. Among the common bases, the order of absorption is found (58) to be thus: Potassium is absorbed more readily than sodium, magnesium more readily than calcium, and ammonium more readily than any of the other bases.

\section{FACTORS INFLUENCING ADSORPTION.}

The amount as well as the kind of surface acting has a great deal to do with adsorption (59). The greater the surface exposed the greater the absorption; hence, clay is a better absorbent than sand or loam (60). The writer found that the more finely fire-clay was powdered, the greater the adsorption of potassium. The ordinary coarsely powdered fire-clay, thirty grams per fifty cubic centimeters of solution, adsorbed in twenty-four hours 0.0171 gram $\mathrm{KCl}$ per $10 \mathrm{c}$. c.; while if the fire-clay was previously ground in an agate mortar for ten or fifteen minutes, the adsorption was 0.0186 gram $\mathrm{KCl}$ per $10 \mathrm{c}$. c. of solution, an increase of over $\mathrm{S}$ per cent. 
Experiments with burnt kaolin when lumpy and powdered, showed an even greater difference.

There is no question but that colloidal materials exhibit much greater absorbing power both as to amount and variety than other materials (61). As mentioned before, van Bemmelen in numerous papers (13) considers the absorptive power of a soil as mainly due to colloidal oxides and silicates, and humus substances (62). Colloids absorb both organic and inorganic compounds.

Now according to the present conception of colloidal materials of the irreversible kind (such as colloidal silicates and oxides), they are regarded as finely divided particles in suspension. According to Noyes (63) colloidal mixtures are defined as liquid (or solid) mixtures of two (or more) substances which are not separated from one another by the action of gravity however long continued, nor by filtration through paper, but which are so separated when the liquid is forced through animal membranes, the substance then remaining behind being designated as the colloid (64). We are concerned in this connection only with irreversible colloids, for the reversible kind such as gelatin are not even coagulated by electrolytes (unless in rery large quantities) (63). Since greater the surface exposed greater the absorption, therefore if the exposed surface be indefinitely multiplied as is the case in colloidal mixtures, then the absorption will reach a maximum in that direction. In other words, colloidal suspensions being in as fine particles as can be obtained, represent that physical state of the absorbent best suited to bring about an abstraction of solutes from solution. When absorbed, coagulation follows, and the whole settles out.

The colloidal material in an absorbent is not essential to absorption, although it does increase the latter. Russian black soil, fire-clay, and kaolin (high grade), were heated to redness in a platinum dish, and kept at that temperature for at least thirty minutes. After cooling each was treated with potassium chloride solution in the proportion of thirty grams to 50 c. c. $\Psi / 10 \mathrm{KCl}$ solution and left in contact for twenty-four hours. Table IV below, the data of which will also be found in Table II, brings out clearly the experimental facts.

Table IV (see also Table II).

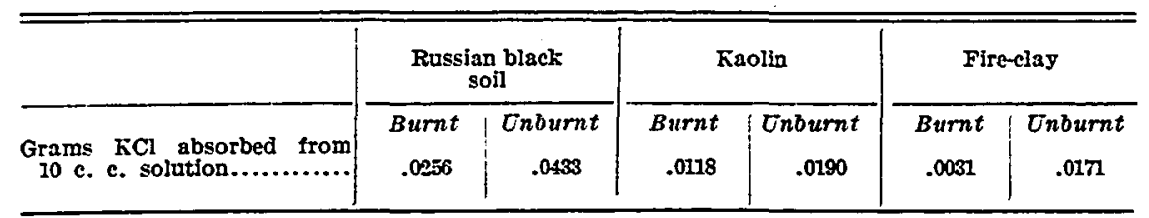


These results indicate that heating decreases but does not destroy the absorptive power, possibly because the colloidal material is coagulated into larger aggregations. Any organic matter present with absorbent was completely destroyed by heating, the Russian black soil becoming a brick-red color. Comparing the amount of sodium passing into solution from burnt and unburnt material, the table indicates that much more was dissolred out of the burnt material, no doubt because heat would tend to break up the sodium minerals.

Time of Adsorption.-The rapidity with which the potassium salt is taken up by the absorbent, when the two come in contact, is a point worthy of notice. Table $V$ brings out the prominent facts in this connection.

T.LBLE V.-(Data taken from Table II.)

\begin{tabular}{|c|c|c|c|c|c|}
\hline Time of digestion & 20 minutes & 5 hours & 24 bours & Weeks & Absorbent \\
\hline 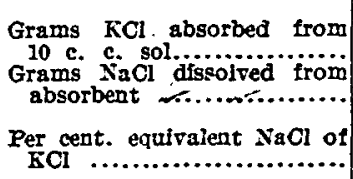 & $\begin{array}{l}.0147 \\
.0024 \\
\text { Percent } \\
21.1\end{array}$ & $\begin{array}{c}.0152 \\
.0012 \\
\text { Per cent } \\
9.9\end{array}$ & $\begin{array}{c}.0147 \\
.0006 \\
\operatorname{Prcent} \\
5.4\end{array}$ & & Limestone soil \\
\hline 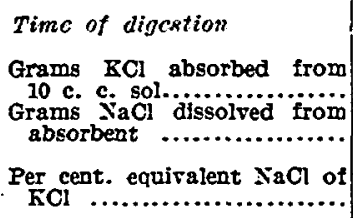 & & & $\begin{array}{l}\text { 24 hours } \\
.0433 \\
.0025 \\
\text { Percent } \\
\pi .3\end{array}$ & $\begin{array}{l}\text { 2 ueeks } \\
.0495 \\
.0015 \\
\text { Per cent } \\
3.8\end{array}$ & Russian biack soll \\
\hline 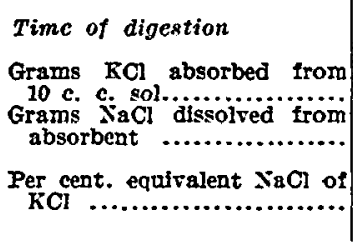 & $\begin{array}{l}.0176 \\
.0036 \\
. \text { Per cent } \\
25.9\end{array}$ & & $\begin{array}{l}24 \text { hours } \\
.017 \\
.0037 \\
\text { Percent } \\
27.0\end{array}$ & $\begin{array}{l}\text { \& uceks } \\
.0184 \\
.0056 \\
\text { Percent } \\
38.7\end{array}$ & Fire-clay \\
\hline
\end{tabular}

From the above results it will be noticed that in some cases there seems to be a partial reabsorption of the sodium. Practically all of the potassium is absorbed as soon as the solution and absorbent come in contact. This lends strong support to the idea that the bulk of the potassium absorbed in the ocean is abstracted as soon as the silt, etc., reaches there. 
These experiments are in accord with Nernst (65) who remarks that equilibrium, in the case of adsorption, is usually reached quickly and exactly. This fact, however, must be borne in mind, a soil is usually a complex adsorbent, sometimes containing both organic and inorganic substances, and this may lead to results not as exact as if it were a simple adsorbent.

Absorption of Acid Radical.-The acid radical is not appreciably absorbed, except in the case of the carbonate radical. This was referred to on p. 18, and references are there given to the literature. The writer's experimental results will now be giren upon the subject. Unless otherwise specified, the proportion of absorbent to solution was thirty grams to fifty cubic centimeters, and 10 c. c., drawn out after filtration of the mixture, were used for analysis. The chlorine was determined gravimetrically as silver chloride; the sulphate gravimetrically as barium sulphate; while the carbonate radical was determined by titration with a normal acid before and after absorption. The experimental results are included in Table VI:

TABLE VI.

\begin{tabular}{|c|c|c|c|c|}
\hline \multirow{2}{*}{$\begin{array}{c}\text { Absorbent } \\
\text { (6 grams to } 10 \text { c. c. } \\
\text { solution) }\end{array}$} & \multicolumn{2}{|c|}{$\begin{array}{l}\text { Grams acid radical } \\
\text { in } 10 \mathrm{c} \text {. c. } \mathrm{K} \text { salt }\end{array}$} & \multirow{2}{*}{$\begin{array}{l}\text { Grams acid } \\
\text { radical ab- } \\
\text { sorbed from } \\
10 \mathrm{c} \text {. }\end{array}$} & \multirow{2}{*}{$\begin{array}{l}\text { Time of } \\
\text { digestion }\end{array}$} \\
\hline & $\begin{array}{l}\text { Betore } \\
\text { absorp- } \\
\text { tion }\end{array}$ & $\begin{array}{l}\text { After } \\
\text { absorp- } \\
\text { tion }\end{array}$ & & \\
\hline 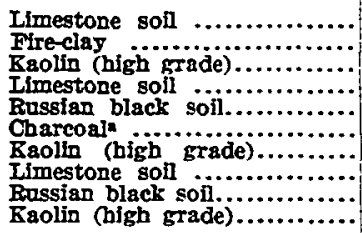 & 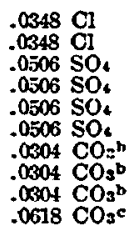 & $\begin{array}{l}.0348 \mathrm{CI} \\
.0348 \mathrm{Cl}^{-0} \\
.0507 \mathrm{SO}_{4} \\
.0484 \mathrm{SO}_{4} \\
.0482 \mathrm{SO}_{4} \\
.0500 \mathrm{SO}_{4} \\
.0245 \mathrm{CO}_{3} \\
.0150 \mathrm{CO}_{3} \\
.0120 \mathrm{CO}_{3} \\
.0516 \mathrm{CO}_{3}\end{array}$ & $\begin{array}{l}\text { None } \\
4 \\
.0028 \mathrm{SO}_{4} \\
.0024 \mathrm{SO}_{4} \\
.0006 \mathrm{SO}_{4} \\
.0059 \mathrm{CO}_{3} \\
.0154 \mathrm{OO}_{3} \\
.0184 \mathrm{CO}_{3} \\
.0102 \mathrm{CO}_{3}\end{array}$ & $\begin{array}{l}3 \text { days } \\
\text { i2 days } \\
24 \text { hours } \\
24 \text { hours } \\
24 \text { bours } \\
24 \text { hours } \\
24 \text { hours } \\
24 \text { hours } \\
24 \text { hours } \\
24 \text { hours }\end{array}$ \\
\hline
\end{tabular}

*In this case the proportions were $1 \frac{1}{2}$ grams absorbent to $10 \mathrm{c}$. c. solntion.

bresent in solution as $\mathrm{K}_{2} \mathrm{CO}_{3}$ (potassium carbonate).

cPresent in solution as $\mathrm{KHCO}_{3}$ (potassinm acid carbonate).

From these results, we find that the chlorine radical is not appreciably absorbed; the $\mathrm{SO}_{4}$ radical is slightly absorbed in most cases; the $\mathrm{CO}_{3}$ radical, unlike the others, is largely absorbed or fixed (purely a chemical reaction). If we compare the weight of $\mathrm{CO}_{3}$ radical fixed with: the weight of potassium absorbed (Table III), we will find them almost equivalent, the carbonate running a little low however. This fixation of the carbonate radical seems to be due to the calcium and magnesium, which passing into solution react to yield the insoluble carbonates. 
The results in Table VII below serve to make this clear:

TABLE VII.

\begin{tabular}{|c|c|c|c|c|}
\hline $\begin{array}{l}\text { Grams metallic } \\
\text { bases dissolred } \\
\text { from absorbent } \\
\text { by } 10 \mathrm{c} \text {. } \\
\text { K= } \mathrm{CO} \text { sol. }\end{array}$ & $\begin{array}{c}\text { Grams K } \\
\text { absorbed from } \\
10 \mathrm{c} \text {. c. } \\
\mathrm{K}=\mathrm{CO} \text { sol. }\end{array}$ & $\begin{array}{c}\text { Grams metallic } \\
\text { bases dlssolved } \\
\text { trom absorbent } \\
\text { bJ } 10 \text { c. c. } \\
\text { KNiOs sol. }\end{array}$ & $\begin{array}{l}\text { Grams } \mathrm{K} \\
\text { absorbed trom } \\
10 \text { c. c. KNOOs } \\
\text { solution }\end{array}$ & Absorbent \\
\hline $\begin{array}{l}.0076 \mathrm{GaO} \\
.0009 \\
.0007 \mathrm{MgO}\end{array}$ & $.0297 \mathrm{~K}$ & $\begin{array}{l}.0124 \mathrm{CaO} \\
.0032 \mathrm{MgO} \\
.0024 \mathrm{Na}\end{array}$ & $.0208 \mathrm{~K}$ & Russian black sóll \\
\hline
\end{tabular}

The solution of potassium nitrate and potassium carbonate were equivalent in strength, approximately $\mathrm{T} / 10$. The time of digestion in each case was twenty-four hours. The abore results indicate, that, even where more potassium is absorbed, very much less calcium and magnesium are found in solution, than where less potassium is absorbed. This difference in the two cases must be due to the fixation in large measure of the calcium-and-magnesium as carbonates. It might be mentioned that when the soil and solution were mixed and corked there was no indication of effervescence.

Absorption of Sodium and Lithium.-The same kind of phenomena govern the absorption of sodium and lithium as that of potassium. The difference is one of degree and not of kind; potassium is absorbed in very much larger amounts. In some cases the absorption of sodium was hardly noticeable. Lithium seems to fall midway between the absorption of potassium and that of sodium.

As in the case of potassium, a solution of sodium chloride was left acid after absorption by fire-clay, and neutral after absorption by Russian black soil, although the amount of free acid could not be determined, so little was it. The lithium chloride which before absorption was slightly alkaline from a small. excess of lithium carbonate, reacted acid after absorption by fire-clay. The other bases apparently pass into solution in a similar manner as in the case of potassium. In order to obtain comparative results the solutions of sodium chloride and lithium chloride were made approximately of the same normality $(1 / 10)$ as that of potassium chloride. The same proportions of absorbent and solution were used as in the case of potassium, and they were in contact for the same length of time. The lithium chloride solution was made from lithium carbonate and normal hydrochloric acid, and was left slightly alkaline. Lithium was determined by the amyl alcohol method. Table VIII below gives 
results showing the amount of absorption of the chlorides of potassium, sodium, and lithium, by fire-clay and Russian black soil, respectively:

TABLE VIII.

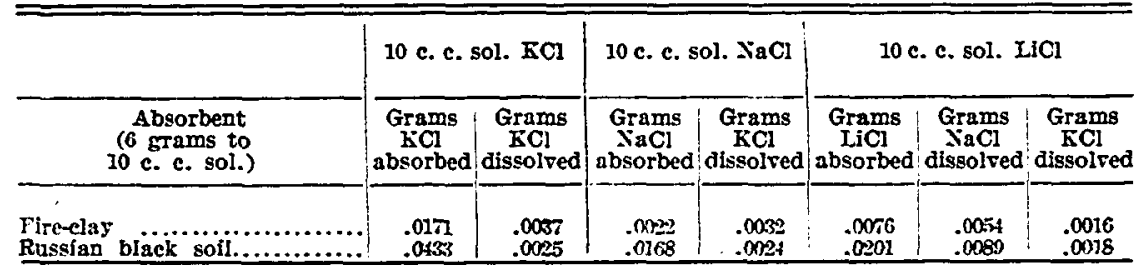

These results indicate that proportionately lithium is absorbed more than sodium, and less than potassium. At the same time, these facts lead apparently to no connection between the degree of absorption and the atomic weights of the above metals.

\section{EXPERTMENTAL WORK INDICATING ADSORPTION OF SODIUM AND IITHIOM.}

The paritition of lithium and sodium chlorides between absorbent and solution follows apparently the laws of adsorption, as does potassium. That is, as the concentration of solution increases, the actual per cent absorbed becomes less. In the case of the Russian black soil, only two concentrations were used, but these indicate the way in which the rule of adsorption is obeyed. Table II below gives the results:

TABLE IX.

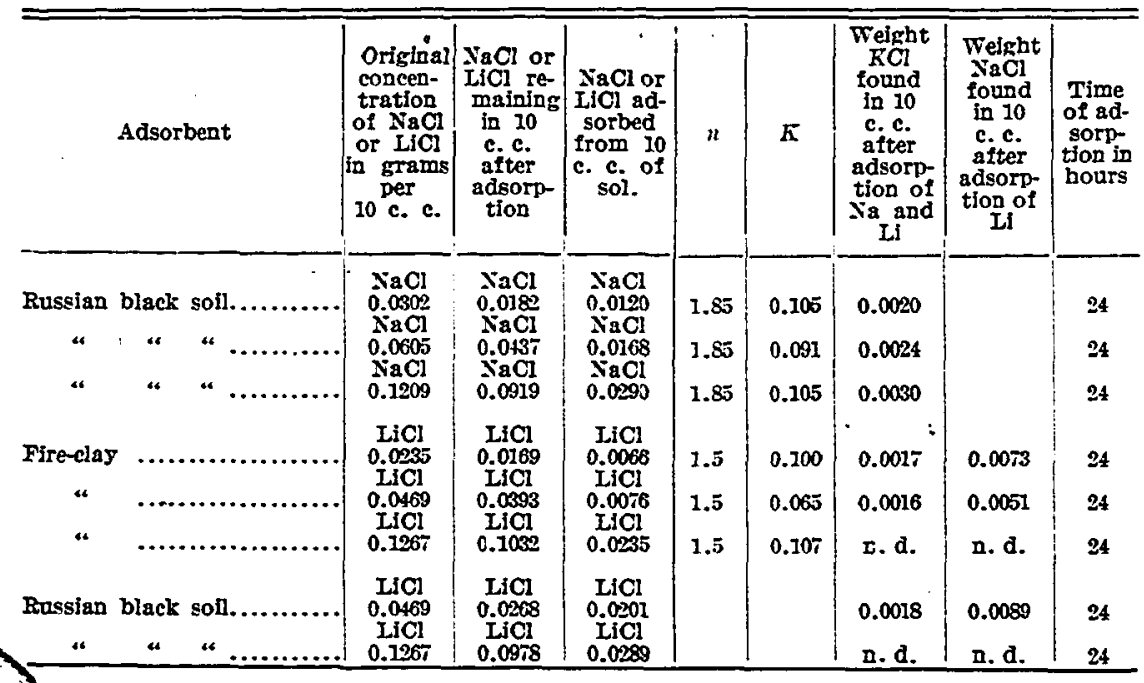




\section{SAIOMON'S WORK ON ABSORPTION OF CAICIUM}

Salomon (66) gives the absorption of calcium by various soils and soil constituents from several concentrations of calcium nitrate solution, to which was added sufficient ammonia to neutralize exactly the nitric acid of the calcium nitrate. His results show the same kind of phenomena as potassium salts. The writer has selected the two cases given below, and from his data has worked out $n$ and $K$. The proportions he (Salomon). worked with were 100 grams to 200 c. c. of solution, or in that ratio.

\section{TABLE X.-(From Salomon's data.)}

\begin{tabular}{l}
\hline \multicolumn{2}{c}{ Absorbent } \\
\hline
\end{tabular}

The Effects of Other Salts Upon Absorption.-Frank (67) found that the absorption of a potassium salt by a soil was lowered by sodium chloride. Treutler (68) in working on the effect of rarious fertilizers upon the absorption of potassium by a soil found that in general the addition of other mineral salts depressed the absorption of potassium, particularly the addition of sodium chloride.

\section{EXPERTMENTAI WORK OF WRITER.}

Using fire-clay and a solution of equivalent amounts of potassium and lithium chlorides, the writer found the absorption of potassium chloride very little affected, while the absorption of lithium chloride was very greatly depressed. Table XI, Part 1, brings out these facts in a concise manner.

TABLE XI.Part 1.

\begin{tabular}{|c|c|c|c|c|c|c|}
\hline \multirow[t]{2}{*}{$\begin{array}{l}\text { Absorbent } \\
(6 \text { grams to } 10 \\
\text { e. c. sol.) }\end{array}$} & \multicolumn{3}{|c|}{$\begin{array}{l}10 \text { c. c. sol. } \mathrm{KCl} \\
\text { and } \mathrm{LiCl}\end{array}$} & \multicolumn{2}{|c|}{$\begin{array}{l}10 \text { c. c. } \\
\text { sol. } \overline{R C l}\end{array}$} & \multirow{2}{*}{$\frac{\begin{array}{c}10 \text { c. c. } \\
\text { sol. LiCl }\end{array}}{\underset{\text { Grams }}{\text { LiCl }}}$} \\
\hline & 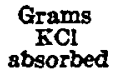 & $\begin{array}{c}\text { Grams } \\
\text { LiCl } \\
\text { absorbed }\end{array}$ & $\begin{array}{c}\text { Grams } \\
\text { NaCl } \\
\text { dissolved }\end{array}$ & $\begin{array}{c}\text { Grams } \\
\mathbf{K C l} \\
\text { absorbed }\end{array}$ & $\begin{array}{c}\text { Grams } \\
\text { JaCl } \\
\text { dissolved }\end{array}$ & \\
\hline$\because \ldots \ldots \ldots+\ldots \ldots \ldots \ldots$ & .0121 & .0027 & .0062 & .0125 & .0049 & .0066 \\
\hline
\end{tabular}


With a solution containing equivalents of potassium and sodium chlorides, using Russian black soil as absorbent, the writer found that sodium chloride lowered the absorption of potassium chloride noticeably, but on the other hand the potassium chloride rery greatly depressed the absorption of sodium chloride, proportionately, rery much more. These results are shown in Table XI, Part 2 .

TABLE XI.-Part 2.

\begin{tabular}{|c|c|c|c|c|c|c|}
\hline \multirow[t]{2}{*}{$\begin{array}{l}\text { Absorbent } \\
\text { (6 grams to } 10 \\
\text { c. c. sol.) }\end{array}$} & \multicolumn{2}{|c|}{$\begin{array}{c}10 \text { c. c. } 801 . \mathrm{KCl} \\
\text { and } \mathrm{NaCl}\end{array}$} & \multicolumn{2}{|c|}{10 c. c. sol. $\mathrm{KCl}$} & \multicolumn{2}{|c|}{$\begin{array}{c}10 \text { c. c. sol. } \\
\mathrm{XaCl}\end{array}$} \\
\hline & $\underset{\text { absorbed }}{\text { Grams }}$ & $\underset{\text { absorbed }}{\text { Grams }}$ & $\underset{\substack{\text { Grams } \\
\text { KCl } \\
\text { absorbed }}}{ }$ & $\begin{array}{l}\text { Grams } \\
\text { NaCl } \\
\text { dissolved }\end{array}$ & $\begin{array}{c}\text { Grams } \\
\text { NaCI } \\
\text { absorbed }\end{array}$ & $\begin{array}{c}\text { Grams } \\
\text { KCI } \\
\text { dissolved }\end{array}$ \\
\hline Russian black soil............ & .0257 & .0067 & .0284 & n. d. & .0120 & n. d. \\
\hline
\end{tabular}

In every case, the solutions used contained the respective chlorides in equivalent amounts.

The presence of calcium chloride in an equivalent amount lowers appreciably the absorption of potassium chloride using fire-clay as absorbent. On the other hand, the presence of magnesium sulphate in equivalent quantity increased the absorption of potassium chloride, using fire-clay as absorbent. The presence of calcium carbonate in excess of an equivalent amount to the potassium chloride raised the absorption of potassium chloride in the case of the limestone soil. These facts are shown in Table XI, Part 3.

TABLE XI.-Part 3.

\begin{tabular}{|c|c|c|c|c|c|c|c|c|}
\hline \multirow[t]{2}{*}{$\begin{array}{c}\text { Absorbent } \\
\text { (6 grams to } \\
10 \text { c. c. sol.) }\end{array}$} & \multicolumn{2}{|c|}{$\begin{array}{l}10 \text { c. c. sol. } \\
\mathrm{KC}+{ }^{2} \text { aCls }\end{array}$} & \multicolumn{2}{|c|}{$\begin{array}{l}10 \text { c. c. }{ }_{\text {. }}^{\text {sol. }} \\
\mathrm{KOO}+\mathrm{MISO}\end{array}$} & \multicolumn{2}{|c|}{$\begin{array}{l}10 \mathrm{c.c} \text {. sol. } \\
\mathrm{KCl} \div \mathrm{CaCO}_{3}\end{array}$} & \multicolumn{2}{|c|}{10 c. c. sol. } \\
\hline & $\begin{array}{c}\text { Grams } \\
\mathrm{KCl} \\
\text { absorbed }\end{array}$ & $\mid \begin{array}{c}\text { Grams } \\
\text { NaCl } \\
\text { dissolred }\end{array}$ & \begin{tabular}{c|} 
Grams \\
KCI \\
absorbed
\end{tabular} & $\begin{array}{c}\text { Grams } \\
\text { NaCI } \\
\text { dissolved }\end{array}$ & $\begin{array}{c}\mathbf{E r a m s} \\
\text { absorbed }\end{array}$ & $\begin{array}{c}\text { Grams } \\
\text { NaCl } \\
\text { dissolved }\end{array}$ & $\begin{array}{c}\text { Grams } \\
\text { KCl } \\
\text { absorbed }\end{array}$ & $\begin{array}{c}\text { Grams } \\
\text { daaO } \\
\text { dissolved }\end{array}$ \\
\hline 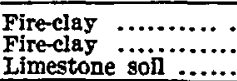 & .0147 & .0045 & .0236 & .0044 & .0182 &, 0060 & $\begin{array}{l}.017 \pi \\
.0171 \\
.0147\end{array}$ & $\begin{array}{l}.0037 \\
.0037 \\
.0006\end{array}$ \\
\hline
\end{tabular}

In the case of kaolin (high grade) the carbonate seemed to retard the absorption of potassium chloride. By reference to the results in Table II, we would expect this difference in the two cases, because we find there that kaolin shows greater absorption of potassium chloride than of potassium carbonate, while the reverse is true with the limestone soil.

The various effects of foreign materials upon the absorption of a given substance seems characteristic of adsorption. According to Bouchonnet 
(39) in studying the adsorption of dyes by ochre, acids affected the adsorption according to no one rule, alkalies greatly retarded adsorption, while sodium chloride accelerated the same.

Temperature Effect.-The writer studied only one case as regards the effect of temperature upon absorption. Fire-clay, in contact with potassium chloride solution, was kept in boiling water for twenty minutes, cooled, and an analysis made upon a portion of the solution. From 10 c. c. only 0.0076 gram $\mathrm{KCl}$ was absorbed, 0.0044 gram $\mathrm{NaCl}$ passed into solution, indicating that higher temperatures retarded absorption. Lagergreen (69) working with dissolved salts and kaolin, animal black, and glass powder, found that adsorption decreases with rising temperature. Bouchonnet (39), in the case of dyes and ochre, found that temperature accelerated adsorption. Freundlich (70), studying adsorption in general, found the temperature effect to be slight. Eridently the effect raries as the kind of materials used differ.

\section{SUMMARY.}

The more inportant points dereloped from this inrestigation may be stated as follows:

1. Absorption of potash from solution is primarily a physical phenomenon known as adsorption, which inrolres chemical reactions as a secondary matter.

2. Adsorption seems to follow hydrolysis of the potassium salt, the base being adsorbed, while the acid combines with any other bases passing into solution. In most cases the acid radical is very little adsorbed. The fixation of the carbonate radical is not adsorption but a simple chemical reaction.

3. The abstraction of potassium is different in degree only from that of sodium and lithium.

4. All evidence points to the fact that potassium is abstracted as flocculation takes place.

5. The presence of other salts affect adsorption of potash variously. Sodium chloride in particular lowers adsorption. On the other hand, potassium salts proportionately retard much more the absorption of salts of sodium and lithium than potassium itself is retarded by the latter two.

6. It seems to depend upon the adsorbent as to what salt of potash shows the greatest adsorption. 
7. Rise of temperature apparently retards the adsorption of potassium.

8. There seems to exist no definite relation betreen absorption of the alkali metals and their atomic weights, the absorption of lithium, the lightest of them, falling between that of potassium and sodium.

\section{ACKNOWLEDGMENT.}

For suggesting this problem along with many helpful hints as to the proper mode of attacking it, the writer wishes to thank Drs. A. C. Spencer and Chase Palmer, of the U. S. Geological Survey, and Professor T. L. Watson, of the geological department of the University of Virginia. To Professors F. P. Dunnington and R. M. Bird, of the chemical department - of the University of Virginia, the writer is deeply indebted for many valuable suggestions. He desires especially to thank Professor Dunnington, under whose kindly guidance the work was done.

University of Virginia,

May, 1913. 


\section{BIBLIOGRAPHY}

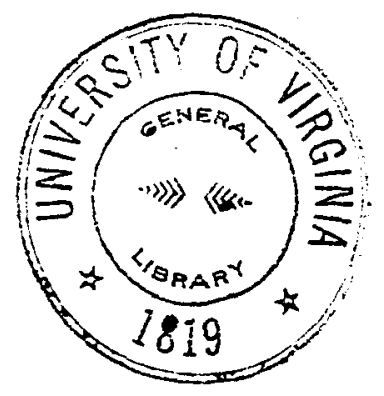

1. Pater ard Waggamax, "Absorption by Soils," Bull. 52, Bureau of Soils, U. S. Dept. of Agric., 1908, Introduction.

2. Peters, Landw. Vers.-Stat., (1S60), 2, 129.

3. The Data of Geochemistry, pp. 477-8.

3. Jour. Ror. Agric. Soc., England, (1850), Vol. II, p. 313; 1852, Vol. XIII, p. 123.

4. The Data of Geochemistry, p. 127.

4. Vax BeMryeres, Landw. Versuchs.-Stationem (Berlin), (1875), Vol. 21, p. 135.

5. The Data of Geochemistry, p. 127.

6. The Data of Geochemistry, p. 12 $\bar{j}$, also various analyses in same.

6. Clarke, "Some Geochemical Statistics," Proc. of Amer. Philo. Soc., pp. 221. $226,228,216-217,218$.

7. CraRkE, "Some Geochemical Statistics," Proc. of Amer. Philo. Soc., p. 224.

8. The Data of Geochemistry, Chap. V.

9. WhEThasr. "Recent Advances in Physical Science," pp. 144-5.

10. Bull. 30, Bureau of Soils, U. S. Dept. of Agric. (1905), p. 65.

11. Bull. 32, Bureau of Soils, U. S. Dept. of Agric. (1906), preface.

12. Bull. 30, Bureau of Soils. C. S. Dept. of Agric. (1906), pp. 52-3.

13. Landw. Vers.-Stat. (1888), 35, 72; Jour. Prakt. Chem. (1881), 23, 324; Zeit. Phrs. Chem. (1895), is, 331: Zeit. Anorg. Chem. (1896), 13, 233; (1898), 18, 14, 98; (1900), 23, 111, 321; (1902), 30, 265; (1904), 35. 23. 33S: Arch. Neer. (1903), (2), 6, 607.

14. Zeit. f. Phys. Chem., R. 2, 759; Landw. Vers.-Stat. (1888), 35, 69.

15. Landw. Vers.-Stat. (1888), 35, 136; also Bull. 52, Bureau of Soils, U. S. Dept. of Agric-p. 26.

10. Bull. 52. Bureau of Soils, U. S. Dept. of Agric., p. 22; Landw. Vers.-Stat. (188S), 35, 69 .

17. Bull. 52, Bureau of Soils, U. S. Dept. of Agric., pp. 16-18; Landw. Vers.-Stat. (1869), 12, 184; (1872), 15, 371.

18. Bull. 52. Bureau of Soils, U. S. Dept. of Agric., p. 32.

19. Zeit. Anorg. Chem. (1900), 23, 321.

20. Bull. 32, Bureau of Soils, U. S. Dept. of Agric. (1906), preface; Cavmeror, "The Soil Solution," p. 62.

21. Zeit. f. Phys. Chem. (1895), 18, 331; Nerxst, "Theoretical Chemistry," p. 426; Zeit. f. Anorg. Chem., 23, 321-372

22. Zeit. f. Phys. Chem., R. 2, 759; see also Landw. Vers.-Stat. (1S88), 35, 69.

23. Zeit. f. Phys. Chem. (1894), 15, 56.

24. Bull. 32, Bureau of Soils, U. S. Dept. of Agric. (1906), preface; Caxrerox, "The Soil Solution," pp. 47-49.

25. Cayrerox, "The Soil Solution," pp. 4i-49; Bull. 32. Bureau of Soils, U. S. Dept. of Agric. (1906), pp. 37-39.

20. Zeit. f. Phrs. Chem. (1900), R. 32, 174; Bijhang. t. K. Svenska Vet. Ak. Handl. (1S99), 24, 2, Nr. 4. 49s.

27. Bull. 52, Bureau of Soils, U. S. Dept. of Agric, p. 74.

2S. Stregltrz, Qual. Anal., Vol. T, 132, 133; see also references given br this author.

29. STIEGLITL. Qual. Anal., Vol. I, 133; HARdx, Proc. Royal Soe. (1899), 66, 110; Zeit. f. Phys. Chem. (1900), 33, 391.

30. WhETHAMr. "Recent Advances in Physical Science." p. 138

31. Bull. 30, Bureau of Soils, U. S. Dept. of Agric. (1905), p. 63.

32. Bull. 30, p. 63; NERxST, "Theoretical Chemistry," p. 426.

33. Journ. Prakt. Chem. (1885), (2), 32. 390-407.

34. Caxresox, "The Soil Solution," pp. 59-60; Bull. 52, Bureau of Soils, U. S. Dept. of Agric., pp. 10-11.

35. Caymerox. "The Soil Solution," p. 60; PAtrex. Trans. Am. Electrochem. Soc. $(1906), 10,67-74$. 
36. Nerxst, "Theoretical Chemistry," p. 499; Zeit. f. Phys. Chem. (1907), 57, 355; see also Lagergrees, Zeit. f. Phys. Chem. (1900), R. 32, 174.

37. Nerisst, "Theoretical Chemistry," p. 499; Ber. Deutsch. Chem. Ges. (1904), $37,3138$.

38. NERist, "Theoret. Chemistry," pp. 123-4.

39. Bodcrosict, "Sur l'adsorption Des Matières Colorantes Par Les Ocres" 8th Inter. Congress of Applied Chemistry, Inorg. Chem. Sect. (1912), II, pp. 53-57.

40. NERxST, "Theoret. Chemistry," p. 499.

41. Jour. Chem. Soc. (1896), 69, 1334.

42. Nersist, "Theoret. Chemistry," p. 124; Bijhang. till K. Sv. Vet. Akad. Handl. (1898), Band. 24, Afd. II, Nos. 4 and 5.

43. Zeit f. Phys. Chem (1907) 57, 469 .

44. Bull 52, Bureau of Soils, U. S. Dept. of Arric.; pp. 26-27. see references mentioned there; Bull. 30, Bureau of Soils, U. S. Dept. of Agric., pp. 52.53.

45. Bull. 52, Bureau of Soils, U. S. Dept. of Agric., p. 27.

46. Bull. 30, Bureau of Soils, U. S. Dept. of Amric., p. 38

47. See references mentioned in Bull. 30, Bureau of Soils, U. S. Dept. of Agric., p. 56.

48. Bull. 30, Bureau of Soils, U. S. Dept. of Agric., p. 45; Jour. Roy. Agric. Soc. (1850), II, 313.

49. Bull. 52, Bureau of Soils, T. S. Dept. of Agric., p. 2S: Zeit. f. Phys. Chem (1907), 59, 284

50. Zeit. f. Phys. Chem. (1905), 45, 321.

51. Bull. 30, Bureau of Soils, U. S. Dept. of Agric., pp. 61-62, numerous references and examples cited; Casmeros. "The Soil Solution," p. 68.

52. Bull. 52. Bureau of Soils, U. S. Dept. of Agric., p. 56.

53. Zeit. f. Phys. Chêm. (1904), 47, 337.

54. Zeit. f. Phys. Chem. (1907), 5i, 421, 468-469: see also Bull. 52, Bureau of Soils, U. S. Dept. of Agric., pp. 60-61.

55. Bull. 52, Bureau of Soils, U. S. Dept. of Agric., p. 61.

56. Rohland, "The Colloidal and Crystalloidal State of Matter," p. 24.

57. Bull. 32, Bureau of Soils, U. S. Dept. of Agric., preface.

58. Bull. 52, Bureau of Soils, U. S. Dept. of Agric., p. 61.

59. Bull. 30, Burean of Soils, U. S. Dept. of Agric. pp. 6l-2: CAMrerox, "The Soil Solution," p. 61

60. Cameron, "The Soil Solution," p. 48.

61. The Data of Geochemistry. p. 488 .

62. Bull. 52. Bureau of Soils, U. S. Dept. of Agric., 20, 26, also references there quoted; Landw. Vers.-Stat. (1888), 35, 136

63. Norzs, "Preparation and Properties of Colloidal Mixtures," Journ. Amer. Chem. Soc., Feb.. 1905, Vol. 38, S6-7: Bull. 52, Bureau of Soils, U. S. Dept of Agric p. 12 .

64. BuLrrzer. "Eine Theorie der Kolloide und Suspensionem." Zeit. f. Phys. Chem. (1903). 45, 307.

65. NERSST. "Theoretical Chemistrr." p. 499.

66. Bull. 52, Bureau of Soils, U. S. Dept. of Agric., pp. 14-15: Landw. Vers.-Stat. (1867) , 9, 351.

67. Bull. 52. Bureau of Soils. U. S. Dept. of Agric., p. 14.

68. Bull. 52, Bureau of Soils. U. S. Dept. of Agric.. p. 18; Landw. Vers.-Stat. (1869), 12, 1S4; (1872). 15. 371.

69. Zeit. f. Phrs. Chem. (1900). R. 32. 174

70. Zeit. f. Phys. (hem. (1907), 5i. I (:" 